\title{
Perbedaan antara Efek Perendaman dalam Susu Sapi dan Susu Kedelai Murni terhadap Kekerasan Email Gigi
}

\author{
Audia N. Hidayat, ${ }^{1}$ Diah A. Purbaningrum, ${ }^{1}$ Sudaryanto, ${ }^{2}$ Nadia Hardini ${ }^{1}$
}

\author{
${ }^{1}$ Departemen Kedokteran Gigi Fakultas Kedokteran Universitas Diponegoro, Semarang, Indonesia \\ ${ }^{2}$ Departemen Parasitologi Fakultas Kedokteran Universitas Diponegoro, Semarang, Indonesia \\ Email: audianh@gmail.com \\ Dikirim: 31 Agustus 2021; direvisi: 19 September 2021; diterima: 21 September 2021
}

\begin{abstract}
Enamel is the hardest structure of the tooth which contains $96 \%$ inorganic material. The hardness of enamel can be observed through the remineralization cycle. Remineralization can be produced by solution that contains ionic calsium and phosphate, such as milk. This study was aimed to determine the difference between immersed in cow milk and in pure soy milk on enamel hardness. This was an experimental laboratory study with the posttest only control group design. Samples were caries-free mandibular first premolars, obtained by using the simple random sampling. There were 27 specimens of human premolars to be measured for enamel hardness divided into three groups, as follows: immersed in artificial saliva, cow milk, and pure soy milk for 90 minutes (assuming consumption of cow milk/pure soy milk for 3 months). The hardness value was tested by using Vickers Hardness Tester with a load of 1000 grams for 10 seconds. The One Way Anova test showed that there were significant differences in tooth enamel surface among groups $(\mathrm{p}<0.05)$. The difference in enamel hardness between the group immersed in cow milk and the one immersed in pure soy milk group was not significant ( $p>0.05)$. In conclusion, there was no difference between immersion in cow milk and in soy milk on the enamel hardness. Cow milk and soy milk can become remineralizing agents to increase the enamel hardness.
\end{abstract}

Keywords: pure cow milk; pure soy milk; hardness of tooth enamel

\begin{abstract}
Abstrak: Email merupakan struktur terkeras dari gigi yang mengandung 96\% bahan anorganik. Kekerasan email dapat diamati melalui siklus remineralisasi. Remineralisasi dapat dihasilkan oleh larutan yang mengandung ion kalsium dan fosfat, salah satunya ialah susu. Penelitian ini bertujuan untuk mengetahui perbedaan antara perendaman dalam susu sapi dan susu kedelai murni terhadap kekerasan email gigi. Jenis penelitian ialah eksperimental laboratorik dengan the posttest only control group design. Sampel penelitian ialah gigi premolar pertama rahang bawah yang bebas karies, diperoleh dengan simple random sampling. Sejumlah 27 spesimen gigi premolar manusia yang diukur kekerasannya dibagi menjadi tiga kelompok yang direndam dalam saliva buatan, susu sapi, dan susu kedelai murni selama 90 menit (asumsi konsumsi susu sapi/susu kedelai murni selama tiga bulan). Nilai kekerasan diuji menggunakan Vickers Hardness Tester dengan beban 1000 gram selama 10 detik. Hasil uji One Way Anova menunjukkan terdapat perbedaan permukaan email gigi yang bermakna $(\mathrm{p}<0,05)$. Perbedaan kekerasan email antara kelompok yang direndam dalam susu sapi dan yang direndam dalam susu kedelai murni tidak bermakna $(\mathrm{p}>0,05)$. Simpulan penelitian ini ialah tidak terdapat perbedaan bermakna antara perendaman dalam susu sapi dan dalam susu kedelai murni terhadap kekerasan email. Susu sapi dan susu kedelai dapat menjadi agen remineralisasi untuk meningkatkan kekerasan email gigi.
\end{abstract}

Kata kunci: susu sapi murni; susu kedelai murni; kekerasan email gigi

\section{PENDAHULUAN}

Karies masih menjadi permasalahan gigi dan mulut pada masyarakat Indonesia dengan nilai prevalensi yang cukup tinggi. ${ }^{1}$ Berdasarkan Survei Departemen Kesehatan Republik Indonesia (SDKI) tahun 2010 
menunjukkan bahwa prevalensi penduduk Indonesia yang menderita karies gigi sebesar $80 \%-90 \% .^{2}$ Hal ini didukung oleh data Riskesdas 2013 yang menunjukkan angka DMF-T (Decay, Missing, Filling Teeth) sebesar 4,6, yang berarti kerusakan gigi pada masyarakat Indonesia sejumlah 460 buah gigi per 100 orang. ${ }^{3}$

Gigi merupakan struktur terkeras di dalam tubuh dengan bagian terluarnya ialah email yang menyelubungi anatomis mahkota gigi. Email merupakan struktur terkeras dari gigi yang mengandung $96 \%$ bahan anorganik yaitu hidroksiapatit. ${ }^{1,4}$ Email memiliki ketebalan yang berbeda di setiap gigi. Ketebalan email pada permukaan insisal dapat mencapai $2 \mathrm{~mm}$, pada bagian cusp premolar 2,3-2,5 mm, cusp molar 2,5-3 mm, dan semakin tipis kearah gingiva. ${ }^{5}$ Email bersifat permeable terhadap ion-ion dan molekul yang dapat berpenetrasi sebagian atau kompleksnya. Email dapat larut atau mengalami demineralisasi ketika berhubungan dengan asam. Larutnya sebagian atau keseluruhan mineral email akan menurunkan kekerasannya dan dapat berakibat terjadinya karies gigi. ${ }^{6}$

Karies merupakan suatu penyakit jaringan keras gigi yang disebabkan oleh aktivitas mikroorganisme dalam suatu karbohidrat yang dapat diragikan dan ditandai dengan adanya demineralisasi. ${ }^{1}$ Demineralisasi gigi adalah larutnya mineral email gigi akibat fermentasi karbohidrat dan menghasilkan asam sehingga $\mathrm{pH}$ menjadi turun sampai 4,5-5,0. ${ }^{4,7}$ Demineralisasi dipengaruhi oleh adanya bakteri pada plak dan karbohidrat. ${ }^{8}$ Mineral gigi dapat disusun kembali melalui proses remineralisasi, dimana kalsium dan fosfat akan mengalami mineralisasi dan membentuk hidroksiapatit. ${ }^{1}$

Remineralisasi adalah tahap pengembalian mineral baru ke dalam gigi yang terdemineralisasi. ${ }^{1}$ Remineralisasi dapat dihasilkan oleh larutan yang mengandung ion fosfat dan kalsium serta dipengaruhi oleh kestabilan lingkungan rongga mulut seperti saliva, kebersihan mulut, fluor, pengendalian plak, dan pola makan yang sehat. ${ }^{1.9}$ Ketika proses demineralisasi lebih besar dibanding proses remineralisasi, maka email gigi akan mengalami karies. ${ }^{8}$
Salah satu hal yang dianggap dapat mengatasi resiko terjadinya karies gigi ialah dengan mengonsumsi susu. Susu dapat mengurangi erosi pada email gigi karena mengandung fosfor, kalsium, laktoferin, fosfat, lemak, serta kasein alami yang baik untuk kesehatan dan dapat melindungi gigi dari karies. ${ }^{1,6}$ Konsumsi susu dapat berupa susu sapi maupun susu kedelai murni. Penelitian Dzulfia et al $^{8}$ menunjukkan susu sapi dan protein whey berpengaruh terhadap peningkatan kekerasan email gigi. ${ }^{8}$ Selain itu, penelitian Widyaningtyas et $\mathrm{al}^{10}$ juga menunjukkan adanya pengaruh susu kedelai terhadap kedalaman mikroporositas email gigi.

Sebagai minuman yang dikonsumsi setiap hari, susu sapi maupun susu kedelai juga dapat digunakan sebagai agen remineralisasi namun belum dilaporkan penelitian mengenai perbedaan perendaman dalam susu sapi dan susu kedelai murni terhadap kekerasan email gigi. Oleh karena itu, penulis terdorong untuk meneliti perbedaan konsumsi susu sapi dan susu kedelai murni sebagai minuman alternatif dalam hal membantu terjadinya remineralisasi gigi.

\section{METODE PENELITIAN}

Penelitian ini dilaksanakan di Laboratorium Terpadu Universitas Diponegoro, dan Laboratorium Preklinik Kedokteran Gigi Universitas Diponegoro, Semarang pada bulan April-Mei 2021. Tujuan penelitian ialah untuk mengetahui perbedaan perendaman dalam susu sapi dan susu kedelai murni terhadap kekerasan email gigi. Jenis penelitian ialah eksperimental laboratorik dengan the posttest only control group design.

Sampel penelitian ini ialah gigi premolar pertama rahang bawah yang bebas karies. Teknik pengambilan sampel yang digunakan ialah simple random sampling. Jumlah sampel pada penelitian ini ialah 27 gigi premolar rahang bawah. Gigi diseleksi dengan kriteria inklusi bebas karies, tidak terdapat fraktur dan retak, tidak terdapat restorasi, tidak terdapat karang gigi di seluruh permukaan gigi.

Persiapan sampel gigi yaitu dipotong di 
bagian servikal menggunakan separating disc untuk memisahkan bagian mahkota dan akar. Dilakukan mounting pada gigi menggunakan resin akrilik dengan bagian bukal menghadap ke atas. Selanjutnya dilakukan pembuatan susu kedelai dengan menimbang 100 gram kedelai kering, dicuci dan direndam selama 8 jam untuk mempermudah pelepasan kulit ari dan melunakkan struktur selular agar memudahkan proses penggilingan. Setelah 8 jam, kulit ari dibuang dan dicuci kembali hingga bersih, kemudian diblender dengan air $100 \mathrm{ml}$, selanjutnya dilakukan penyaringan ampas kedelai. ${ }^{9}$

Pengukuran $\mathrm{pH}$ pada ketiga larutan dilakukan sebelum perendaman menggunakan $\mathrm{pH}$ meter digital. Perendaman dilakukan pada seluruh spesimen dengan membaginya kedalam tiga kelompok. Kelompok pertama direndam dalam saliva buatan sebagai kontrol. Kelompok kedua direndam dalam susu sapi murni, dan kelompok ketiga direndam dalam susu kedelai murni. Perendaman dilakukan selama 90 menit (dengan asumsi konsumsi susu sapi/susu kedelai murni selama 3 bulan /1 satu kali konsumsi selama 1 menit) di dalam inkubator dengan suhu $37^{\circ} \mathrm{C}$ menyesuaikan kondisi rongga mulut. ${ }^{6}$ Selanjutnya, dilakukan uji kekerasan email pada tiap spesimen secara berurutan menggunakan Vickers Hardness Tester.

Normalitas data penelitian diuji dengan menggunakan uji Shapiro Wilk. Uji One Way Anova dilakukan untuk mengetahui perbedaan rerata kekerasan email gigi pada seluruh kelompok dan dilanjutkan dengan uji post hoc Games-Howell untuk mengetahui perbedaan kekerasan email pada kedua kelompok.

\section{HASIL PENELITIAN}

Uji normalitas dengan uji Shapiro Wilk menunjukkan distribusi normal dengan nilai $\mathrm{p}>0,05$. Hasil uji homogenitas menunjukkan data tidak homogen $(\mathrm{p}<0,05)$ sehingga pengujian dilakukan menggunakan uji One Way Anova, dilanjutkan dengan uji post hoc Games-Howell.

Tabel 1 memperlihatkan nilai rerata kekerasan (diuji dengan Vickers Hardness Number/VHN) setelah perendaman selama 90 menit. Nilai rerata tertinggi terdapat pada kelompok susu sapi, diikuti susu kedelai, dan nilai rerata terendah pada kelompok saliva buatan sebagai kontrol.

Tabel 1. Hasil rerata pengukuran nilai kekerasan permukaan email gigi

\begin{tabular}{lc}
\hline \multicolumn{1}{c}{ Kelompok } & Mean \pm SD \\
\hline Saliva buatan & $371,82 \pm 9,08$ \\
Susu sapi murni & $398,07 \pm 14,91$ \\
Susu kedelai murni & $388,78 \pm 4,61$ \\
\hline
\end{tabular}

Tabel 2 memperlihatkan hasil uji One Way Anova dengan nilai $\mathrm{p}<0,05$ yang menandakan terdapat perbedaan kekerasan yang bermakna dari selisih pada masingmasing kelompok uji.

Tabel 3 memperlihatkan hasil uji post hoc Games-Howell. Hasil uji menunjukkan terdapat perbedaan antara kelompok kontrol dengan kelompok perlakuan. Bila perendaman dalam susu sapi murni dibandingkan dengan perendaman dalam susu kedelai murni diperoleh kekerasan email hampir sama, yang berarti perbedaan tidak bermakna ( $p>0,05)$. Namun jika dibandingkan dengan perendaman dalam saliva buatan, keduanya menunjukkan perbedaan bermakna $(\mathrm{p}<0,05)$.

Tabel 2. Hasil uji One Way Anova

\begin{tabular}{ccccc}
\hline & Sum of squares & Df & F & Sig. \\
\hline Antar Perlakuan & 3187,636 & 2 & 14,669 & 0,000 \\
Dalam Perlakuan & 2607,691 & 24 & & \\
Total & 5795,327 & 26 & & \\
\hline
\end{tabular}

*Bermakna: $p<0,05$ 
Tabel 3. Hasil uji post hoc Games-Howell

\begin{tabular}{clll}
\hline \multicolumn{1}{c}{ I } & \multicolumn{1}{c}{ II } & p & Keterangan \\
\hline Saliva buatan & Susu sapi & 0,002 & Bermakna \\
& Susu kedelai murni & 0,001 & Bermakna \\
Susu sapi murni & Susu kedelai murni & 0,226 & Tidak bermakna \\
\hline
\end{tabular}

*Bermakna $<0.05$

\section{BAHASAN}

Penelitian ini bersifat eksperimental laboratorik yang bertujuan untuk mengetahui perbedaan perendaman dalam susu sapi dan susu kedelai murni terhadap kekerasan email gigi. Sampel yang digunakan pada penelitian ini ialah gigi premolar satu rahang bawah yang bebas karies.

Sampel dibagi menjadi tiga kelompok. Kelompok pertama direndam dalam saliva buatan sebagai kontrol; kelompok kedua direndam didalam susu sapi murni; dan kelompok ketiga direndam dalam susu kedelai murni. Perendaman dilakukan selama 90 menit (dengan asumsi konsumsi susu sapi/susu kedelai murni selama 3 bulan /1 kali konsumsi selama 1 menit) di dalam inkubator dengan suhu $37^{\circ} \mathrm{C} .{ }^{8}$

Saliva buatan digunakan sebagai kontrol karena mengandung kalsium klorida, natrium klorida, magnesium klorida, dipotassium hydrogen orthophosphate, dan kalium fosfat yang adekuat dalam mendukung terjadinya remineralisasi. ${ }^{8}$ Komponen anorganik ini sama dengan kandungan saliva normal, seperti $\mathrm{Na}^{+}, \mathrm{K}^{+}, \mathrm{Ca}^{2+}, \mathrm{Mg}^{2+}$, $\mathrm{Cl}^{-}, \mathrm{HCO}_{3-}$ dan fosfat. ${ }^{10}$ Hal ini sejalan dengan penelitian oleh Rezvani et $\mathrm{al}^{11}$ yang menggunakan saliva buatan sebagai kontrol. Kekerasan email yang tinggi pada kelompok kontrol disebabkan karena kandungan mineral yang terdapat di saliva buatan adekuat untuk terjadinya remineralisasi. ${ }^{8}$

Berdasarkan hasil penelitian kelompok kontrol memiliki rerata kekerasan email sebesar 371,82, sedangkan pada kelompok perendaman dalam susu sapi sebesar 398,07 dan pada perendaman dalam susu kedelai sebesar 388,78 . Nilai rerata kelompok susu sapi dan kelompok susu kedelai memiliki nilai kekerasan yang lebih tinggi dibandingkan saliva buatan. Magalhães et $\mathrm{al}^{12}$ membuktikan bahwa secara in vitro susu dapat mengurangi erosi pada email secara bermakna. Hal ini juga sejalan dengan penelitian Dzulfia et $\mathrm{al}^{8}$ yang mendapatkan peningkatan kekerasan email pada kelompok perendaman dalam susu sapi maupun whey yang lebih tinggi daripada kelompok kontrol. ${ }^{8}$

Susu memiliki sifat yang menyerupai larutan remineralisasi. ${ }^{10}$ Proses remineralisasi dapat terjadi jika $\mathrm{pH}$ netral dan terdapat ion $\mathrm{Ca} 2+$ dan $\mathrm{PO} 43-$ dalam jumlah yang cukup. ${ }^{13}$ Pada penelitian ini susu sapi memiliki pH 6,6 dan 100 gram susu sapi murni mengandung $276 \mathrm{mg}$ kalsium dan 842 $\mathrm{mg}$ fosfor, sedangkan pada susu kedelai $(\mathrm{pH}$ 6,3 ), dalam setiap 100 gram biji kedelai terdapat $196 \mathrm{mg}$ kalsium dan $506 \mathrm{mg} .{ }^{10,14}$

Pada awalnya mineral kalsium dan fosfor akan terdeposit pada lapisan permukaan mikroporositas, kemudian mineral berdifusi masuk ke dalam mikroporositas email. Mineral yang masuk dapat berdifusi ke segala arah di antara kristal enamel kemudian diserap oleh hypomineralized enamel, yaitu enamel yang sebelumnya mengalami demineralisasi. ${ }^{10,15}$ Selain itu kandungan fluor dalam susu dapat berikatan dengan hidroksiapatit secara kimia sehingga membentuk fluoroapatit. ${ }^{8}$

Proses remineralisasi merupakan proses penting yang memiliki pengaruh secara bermakna pada kekerasan dan kekuatan gigi. Susu merupakan agen remineralisasi yang baik karena memiliki kandungan kalsium dan fosfor. ${ }^{1}$ Susu kedelai merupakan produk hasil ekstraksi kedelai dengan menggunakan air, yang mempunyai penam- 
pakan dan nilai gizi mirip dengan susu sapi. Susu kedelai mengandung serat kasar dan tidak mengandung kolesterol sehingga cukup baik bagi kesehatan. Selain itu susu kedelai tidak mengandung laktosa sehingga dapat dikonsumsi oleh penderita dengan intoleran laktosa. ${ }^{16-17}$

Hasil uji One Way Anova menunjukkan adanya perbedaan bermakna pada ketiga kelompok. Hal ini disebabkan karena saliva buatan, susu sapi, dan susu kedelai murni memiliki kandungan mineral yang dapat memengaruhi kekerasan email gigi melalui siklus remineralisasi. Pengujian dengan uji post hoc Games-Howell mendapatkan kelompok perlakuan susu sapi dan susu kedelai menunjukkan perbedaan tidak bermakna atau sama $(p>0,05)$. Berbeda halnya antara kelompok yang direndam dalam susu sapi dengan saliva buatan yang menunjukkan perbedaan bermakna $(p<0,05)$. Demikian pula antara kelompok yang direndam dalam susu kedelai dengan saliva buatan menunjukkan perbedaan bermakna $(\mathrm{p}<0,05)$.

Penelitian oleh Dzulfia et $\mathrm{al}^{8}$ mendapatkan bahwa terdapat perbedaan bermakna antara kelompok perendaman dalam saliva buatan dengan susu sapi maupun protein whey tetapi pada kelompok susu sapi dengan protein whey menunjukkan perbedaan tidak bermakna. Tjandrawinata dan Andreas ${ }^{18}$ meneliti efek perendaman dalam air jeruk nipis dan air jeruk lemon terhadap kekerasan permukaan semen ionomer kaca dan menunjukkan perbedaan kekerasan email gigi yang tidak bermakna oleh karena $\mathrm{pH}$ yang tidak jauh berbeda. Pada penelitian ini didapatkan adanya perbedaan kekerasan email gigi yang tidak bermakna antara perlakuan perendaman dalam susu sapi murni dan susu kedelai murni; hal ini dimungkinkan karena kandungan mineral dan $\mathrm{pH}$ pada kedua jenis susu tidak berbeda jauh.

\section{SIMPULAN}

Tidak terdapat perbedaan bermakna antara perendaman dalam susu sapi dan dalam susu kedelai murni terhadap kekerasan email. Susu sapi dan susu kedelai dapat menjadi agen remineralisasi untuk meningkatkan kekerasan email gigi.

\section{Konflik Kepentingan}

Penulis menyatakan tidak terdapat konflik kepentingan dalam studi ini.

\section{Ucapan Terimakasih}

Ucapan terimakasih disampaikan kepada semua pihak yang telah terlibat dalam penelitian 'Perbedaan perendaman susu sapi dan susu kedelai murni terhadap kekerasan email gigi' di Laboratorium Terpadu Universitas Diponegoro, Semarang sehingga hasil penelitian dapat dituangkan dalam bentuk artikel ilmiah.

\section{DAFTAR PUSTAKA}

1. Putri AD, Rahmawati AD. Perbedaan kekerasan email gigi desidui antara sebelum dan sesudah perendaman dengan beberapa jenis sediaan susu. Yogyakarta: Universitas Muhammadiyah Yogyakarta; 2016. Available from: http://repository. umy.ac.id/bitstream/handle/123456789/ 7305/12.\%20NASKAH\%20PUBLIKA SI.pdf?sequence $=12 \&$ is Allowed $=\mathrm{y}$

2. Depkes RI. Laporan Hasil Riskesdas Indonesia Tahun 2010. Jakarta: Badan Penelitian dan Pengembangan Kesehatan, 2010.

3. Depkes RI. Laporan Hasil Riskesdas Indonesia Tahun 2013. Jakarta: Badan Penelitian dan Pengembangan Kesehatan, 2013.

4. Ortner DJ, Putschar WGJ. In: Buikstra J, editor. Ortner's Identification of Pathological Conditions in Human Skeletal Remains (3rd ed). Elsevier, 2019. eBook ISBN 9780128099018.

5. Hamzah Z, Indriana T, Indahyani DE, Barid I. Sistem Stomatognati (Pengunyahan, Penelanan, dan Bicara). Yogyakarta: Penerbit Deepublish, 2020.

6. Rahayu F. Perubahan kekerasan email pada permukaan gigi setelah direndam soft drink berkarbonasi. Jurnal Wiyata. 2017;4(1):31-6.

7. Asmawati. Potensi cangkang udang (Litopenaeus vannamei) sebagai bahan remineralisasi gigi. Makassar Dent J. 2018; 7(1):46-9.

8. Dzulfia L, Damiyanti M, Herda E. Pengaruh susu sapi dan protein whey terhadap kekerasan email gigi setelah demineralisasi. Jurnal Material Kedokteran Gigi. 2016;2(5):28-35.

9. Zulsantritus, Edrizal, Busman. Potensi remineralisasi pada pasta gigi berflorida dan 
tidak berflorida. Jurnal B-Dent. 2016; 3(2):139-44.

10. Widyaningtyas V, Rahayu YC, Barid I. Analisis peningkatan remineralisasi enamel gigi setelah direndam dalam susu kedelai murni (Glycine max(L.) Merill) menggunakan scanning electron microscope (SEM). Jurnal Pustaka Kesehatan. 2014;2(2):258-62.

11. Rezvani MB, Karimi M, Akhavan R, Haghgoo R. Comparing the effects of whey extract and casein phosphopeptideamorphous calcium phosphate (CPPACP) on enamel microhardness. J Dent Shiraz Univ Med Sci. 2015;16(1):49-53.

12. Magalhães AC, Levy FM, Souza BM, Cardoso CAB, Cassiano SP, Pessan JP, Buzalaf MAR. Inhibition of tooth erosion by milk containing different fluoride concentrations: an in vitro study. J Dent. 2014;42(4):498-502.

13. Jenanny KH, Lunardi CGJ, Subiyanto A. Kemampuan bioaktif glass (Novamin) dan casein peptide amorphous calcium phosphate (CPP-ACP) terhadap demineralisasi enamel. Conservative Dentistry Journal. 2017;7(2):111-9.

14. Rukmana, Rahmat. Kacang Hijau dan Budi Daya Pasca Panen. Yogyakarta: Kanisisus, 1997.

15. Barbakow F, Imfeld T, Lutz F. Enamel remineralization: how to explain it to patients. Journal of Preventive Dentistry Quintessence International. 1991;22(5):14.

16. Tuhumury HCD. Effect of water addition in the processing of soya milk. Jurnal Teknologi Pertanian. 2015;4(1):8-13.

17. Muawannah A. Pengaruh lama inkubasi dan variasi jenis starter terhadap kadar gula, asam laktat, total asam dan $\mathrm{pH}$ yoghurt susu kedelai. Jurnal Valensi. 2007;1(1): $1-6$.

18. Tjandrawinata R, Andreas J. Efek perendaman air jeruk nipis dan air jeruk lemon pada kekerasan permukaan semen ionomer kaca. Jurnal Material Kedokteran Gigi. 2018;7(2):11-6. 